\title{
Authority to Cancel The Judge Agreement as Evidence of Cancellation of Grants Authentic Act and Sale Agreement
}

\begin{abstract}
Umar Al Faruq ${ }^{1}$ and Akhmad Khisni ${ }^{2}$
Abstract. This study aimed to analyze the authority of the judge, analyze the civil law, and to determine the factors that are considered by the judge in dismissing the notarial agreement as authentic evidence regarding the cancellation of the grant agreement and the agreement of sale. Authentic agreement is a legal cover, which had a value of legal certainty and the strength of evidence that is perfect for the parties to make. The existence of an authentic agreement due to provisions. legislation that would require such evidence to certain legal acts of the parties calls for certain legal actions embodied in the form of an authentic agreement. As for the issues that arises is how power law Notary agreement as evidence and what criteria which determine the handicap of a notarial agreement so that it can be canceled by the court. This research is research Empirical research juridical or legal research library (library research). Data were analyzed using qualitative research, is sorting and preparation of data classification, editing data and coding data for building performance analysis data, conduct data analysis in accordance with the construction of the discussion of the research results.

Keywords: Judge Authority; A Notary; The Authentic Act Of Cancellation; The Grant Agreement; Sale Agreement.
\end{abstract}

\section{Introduction}

Notaries are General Authorities are the only one authorized to make authentic act of all making the agreement and the determination required by the General Regulation or by the concerned desired to be stated in an authentic agreement, ensure certainty the date, save the agreement and give Grosse, copies and excerpts, all along the agreement was by a general rule not also be assigned or excluded to the official or other person. ${ }^{3}$

The notarial agreement as an authentic agreement is made according to the form and procedure set forth in Article 38 until Article 65 UUJN. ${ }^{4}$ An agreement to be authentic if eligible predetermined law, therefore, a notary in carrying out these duties shall: "... carry out their duties with discipline, professional and moral integrity should not be in doubt. What is stated in the beginning and end of which is the responsibility notary agreement is an expression that reflects the true situation at the time of an agreement". 5

Judges are positions that have the responsibility to receive, process, and decide the case until the problems do not arise again in the future. If the law is unclear, incomplete, or even no, then the judge should seek legal or perform legal discovery (rechtsvinding) its meaning authorities include, authorities against the person, which is

\footnotetext{
${ }^{1}$ Student of Master Program in Notary Program UNISSULA email aminproperty63@gmail.com

2 Lecturer of Faculty of Law UNISSULA

${ }^{3}$ Notary Regulations Article 1 Stb 1860-31 compiled by GHS Lumban Tobing in Muchlis Fatahna et al 2003 Notary Talking about the State Watampone Press Jakarta p 253

${ }^{4}$ Abdul Ghofur Ansori 2009 Lembaga Kenotariatan Indonesia: Perspektif Hukum dan Etika Yogyakarta: UII Press p. 16.

5 Tan Thong Kie 2000 Studi Notariat-Serba Serbi Praktek Notaris Jakarta: Ichtiar Baru Van Hoeve p. 166.
} 
for the benefit of whom the agreement was made or intended by the person of interest. Authorized to an agreement, which is authorized to make the authentic act on all agreements, agreements and statutes that required the Act or desired in question. As well as to the time and the competent authorities of the place, which is as per the domicile and the area office of Notary and Notary guaranteeing the time listed in the agreement $^{6}$,

Cancellation agreement land grant by the Religious Courts $1 \mathrm{~A}$ class Pamekasan with Case Number: 1131 / Pdt.G / 2011 / PA. Pmk, between Plaintiffs I First (Plaintiff I), Plaintiff II Original (Plaintiff II), Plaintiff III Original (Plaintiff III) against Defendant I First (Defendant I), Defendant II Original (Defendant II), and the Notary / PPAT (CoDefendants ) which have been reported to the Supervisory Board / Audit Notary of Pamekasan. The case began on the First Defendant I and Defendant Counsel First I had purchased a piece of land from land owners with the Agreement of Sale and Purchase Agreement No. 166 / PPAT / B / KT / 1988, which was made by the Land Agreement Official (abbreviated PPAT) by Djojonegoro. The land area is an area of 36,247 M2 (square meters) with a limit - a limit as follows:

- North side adjacent to land owned by the Foundation.

- South side is bordered by a local road.

- West of Guangxi bordering the village road.

- East borders by land owned by the landowner I.

In such cases, the second defendant Defendant I went to sign a letter that explained the purpose of his letter was the second defendant to break the land certificate, so that each - each heir gets his share. So both of them went to R. Ahmad Ramali Notary Office is located at Jl. Orange No. 6 Pamekasan. Some time later, the Defendant First I found out that the signing of the letter is not an agreement to break the land certificate but a Grant Agreement No. 351 / Pmk / 2002 made by PPAT Ramali R. Ahmad, SH Whereas grant agreement referred unbeknownst first defendant, because the second defendant has been deceit and persuasion to the defendant I. Therefore, Defendant I had to make a statement in advance and known by the local village chief on the staircase Suparjo August 6, 2008. The contents of statement made essentially cancel and revoke the Agreement of Grant No. 351 / Pmk / 2002 to avoid conflicts and problems of children - children in the future.

Those problems on the central theme of the study authors. With this research is expected the public to know and understand about the law of treaties, and to always be careful to make a treaty which was made in violation of the provisions of the law, especially the Notary as a public official, because after all deviations made in the preparation of an agreement, a time will be sticking to the surface and it will be a problem, of course, will cause harm to others and those who do such deviations.

\section{Research Methods}

Research type used in this study using empirical research juridical or legal research library (library research. The approach used in this thesis is the approach Legislation Case law and approach / field.

Data collection techniques used in this study using two techniques, namely: Observations with direct observation to the location of the research conducted, as well as methods of literature study.

\footnotetext{
${ }^{6}$ Habieb Adjie 2009 Meneropong Khasanah Notaris dan PPAT Indonesia Bandung PT. Citra Aditya Bakti p. 14
} 
Data were analyzed using qualitative research, is sorting and preparation of data classification, editing data and coding data for building performance analysis data, conduct data analysis in accordance with construction research.

\section{Results And Discussion}

Notary has been known in our country, since the Dutch colonized in Indonesia, because the notary is an institution that is already known in their lives in their own homeland. ${ }^{7}$ The existence of the Notaries in Indonesia is always associated with the presence of the faculty of law, it is evident from the institution that produces Notary everything from law school with a specialty Notary Education Program Specialist or the current Master of Notary. ${ }^{8}$

Notaries are General Authorities are the only one authorized to make authentic act of all making the agreement and the determination required by the General Regulation or by the concerned desired to be stated in an authentic agreement, ensure certainty the date, save an agreement and give Grosse, copies and excerpts, all along the agreement was by a general rule not also be assigned or excluded to the official or other person. ${ }^{9}$

For an authentic agreement, the agreement has three functions to the parties that made it in the form of:

- As evidence for the parties that what is written in the agreement is the goal and desire of the parties;

- As evidence for the parties that what is written in the agreement is the goal and desire of the parties;

- As a proof to third parties that on a certain date unless specified otherwise, the parties have entered into an agreement and that the agreement in accordance with the will of the parties

The responsibility of a notary when viewed from Act No. 30 of 2004 concerning Notary is very closely related to the duties and work of notaries. It was said, because in addition to making authentic agreements, notaries are also assigned and is responsible for registering and endorsed (waarmerken and legalization) papers / agreements are made under the hand.

After the case investigation is carried out, the judge collects all the examination results to be filtered which is important and what is not important. Based on the results of the examination, the judges tried to find events (feitvinding, fact finding). Once the judges have certainty that the event has occurred, and then determine whether the events that have occurred are against the law or not. Then, the judges determine whether the legal regulations which mastered the events that have happened. This is called finding the law (rechtsvinding, law finding). When the judges have found legal events and then immediately ruled it examines is called a "verdict".

Judges are positions that have the responsibility to receive, process, and decide the case until the problems do not arise again in the future. If the law is unclear, incomplete, or even no, then the judge should seek legal or perform legal discovery (rechtsvinding). The major role of judges in line with the principle that the Republic of Indonesia is a country of law and the consequences according to the Constitution of

\footnotetext{
${ }^{7}$ R. Soegono Notodisoerjo 1993 Hukum Notariat Di Indonesia Suatu Penjelasan Cetakan 2 PT. Raja Grafindo Persada Jakarta p 1.

${ }^{8}$ Ibid.

${ }^{9}$ Notary Regulations Article 1 Stb 1860-31 compiled by GHS Lumban Tobing in Muchlis Fatahna et al 2003 Notary Talking about the State Watampone Press Jakarta p 253
} 
the Republic of Indonesia Of 1945 (NRI Constitution of 1945) determined the existence of an independent judiciary and free from the influence of government power. Judicial Power following the judge stipulated in Chapter IX of the Constitution NRI Of 1945 regarding Judicial Power that is in Article 24, Section 24A, 24C, and Article 25.

The judge in the Supreme Court and judges at judicial bodies underneath it in the public courts, religious courts, military courts, administrative courts, and judges at a special court within the judicial environment.

Status of judges as state officials initially set out in Article 1 paragraph 1 of Law No. 28 of 1999 on State Officials Clean and Free from Corruption, Collusion and Nepotism (Law on State) (Official Gazette of the Republic of Indonesia Of 1999 Number 75, Supplement the Republic of Indonesia Number 3851), which explicitly states the following, "the organizers of the state is the state officials who perform the function of the executive, legislative, or judicial and other officials whose functions and their main tasks associated with the administration of the state in accordance with the provisions of the legislation in force ".

The position of a judge as a state official is also stated in Article 19 of the Judicial Power Law which states that "Justice and Constitutional Judges are state officials who perform judicial authority set out in statute." Later in the development status of judges was also re-affirmed as stated in Article 122 ASN letter e Law which states that the State officials are "chairman, deputy chairman, the young chairman and justices on the Supreme Court and the chairman, vice chairman, and judges at all judicial bodies except the judge ad hoc". Should be noted in this recent development is the Law of the Ad Hoc ASN issuing judge of the definition of "judges" who are classified as state officials. ${ }^{10}$,

As for the Constitutional Court Decision No. 32 / PUUXII / 2014 which was read on April 20, 2015, the Constitutional Court (MK) reinforces the concept that an ad hoc judge is not included in the definition of judges who are classified as state officials. The Court found the appointment of judges of the Ad Hoc done through a selection process that is not the same as the recruitment and appointment of judges as state officials in general. In addition, the original purpose of the establishment of the Ad Hoc judge is to strengthen the role and function of the judicial power in enforcing the law and justice in line with the complexity of the existing case. Ad hoc judges are judges non carrier who have the expertise and ability to prosecute a particular case. Ad Hoc Judge may have a positive effect when a judge ad hoc joint career judge handles a case so that in the decision the Court considered that Article 122 e of Law ASN NRI is not contrary to the Constitution of 1945 . However, in consideration of the decision, the Court argued that the determination of the judge Ad Hoc as a state official is an open legal policy (open legal policy) which at times can be changed by the legislators. Thus the determination of state officials who are excluded qualification for Ad Hoc judge fully the authority of the legislators The Court found the judge ad hoc determination as a state official is an open legal policy (open legal policy) which at times can be changed by the legislators. Thus the determination of state officials who are excluded qualification for Ad Hoc judge fully the authority of the legislators The Court found the judge ad hoc determination as a state official is an open legal policy (open legal policy) which at times can be changed by the legislators. Thus the determination of state

\footnotetext{
10 Taufiqurrohman Syahuri Hakim Pasca UU Aparatur Sipil Negara Minutes Results Discussion Organized by the Institute for Research and Advocacy for Independence of the Judiciary (LeIP) together with Judge Discussion Forum Indonesia (FDHI) January 252014.
} 
officials who are excluded qualification for Ad Hoc judge fully the authority of the legislators ${ }^{11}$,

The verdict is a statement by the judge as a state official who is authorized, spoken in court and aim to end or settle a problem or dispute between the pihak.14 The judge's decision is part of the decision within the scope of the Religious Courts. In addition to the scope of the decision in the religious courts, also known as the designation. The difference between them is that You keep it in it does not contain the dispute, but it contains a ruling on the dispute.

Thus, the judges of the Religious Court Pamekasan in deciding the validity of the Agreement of Grant Number: 351 / Pmk / 2002 made by Notary / PPAT referring to Islamic law, positive law (KHI), and jurisprudence(the Supreme Court decision RI) decided that the grants made by Defendant I to Defendant violate Islamic law and the Grant Agreement in substance has violated legal provisions applicable in Indonesia today.

It means that the substance of the Agreement of Grant No. 351/2002 / PA. Pmk, Notary / PPAT R. Ahmad Ramali, SH law is flawed, because it does not comply with applicable law. The third runway (Islamic law, KHI, the decision of the Supreme Court) is exactly what the legal basis for Pamekasan Religious Court Judge in deciding the validity of the Agreement of Grant.

If the Notary / PPAT have otherwise been violated provisions of the Compilation of Islamic Law, means a notary public / PPAT in making an agreement have violated laws and regulations in force which is one of its obligations. Thus, the notary must be penalized in accordance with the rules on the sanctions that have been regulated in the Law on Notary. Penalties could include civil penalties and administrative sanctions. In terms of civil sanctions, then the plaintiff can ask for compensation to the defendants, including the Notary / PPAT as a co-defendant in the case of cancellation of the agreement of grant in the Religious Court Pamekasan.

\section{Closing}

\subsection{Conclusions}

- Based on the description in the previous chapter, obtained some conclusions as follows post of judge in the administration of state government is currently not regulated in the legislation.

- Judge Position settings in the legislation at this time is not in accordance with the law and politics of the times include the presence of Act No. 5 of 2014 on State Civil Administrative and Constitutional Court Decision No. 32 / PUU-XII / 2014 regarding testing Act No. 5 of 2014 on the Civil Administrative State against the Constitution of the Republic of Indonesia Of 1945.

\subsection{Suggestion}

In order to provide legal justice should judge had no view unlimited freedom in the proceedings in the trial. The judge may overstep the legal provisions, but which can be bypassed it only substantive legal provisions, when it applied the substantive law provisions will lead to the feeling of unfairness for both litigants. However, if that were bypassed the procedural law (formal) then happens to the parties concerned with the case of the case will feel unfairly treated. While in case I researched this matter

\footnotetext{
${ }^{11}$ The Constitutional Court the Constitutional Court Decision No. 32 / PUUXII / 2014 Testing Act No. 5 of 2014 on the Civil Administrative State against the Constitution of the Republic of Indonesia of 1945 April 202015 p. 111-112.
} 
needed to obtain substantive justice for the grant agreement and the agreement of sale.

\section{References}

[1] Bagir manan Peranan Pedoman Tingkah Laku Hakim Sebagai Penjaga Kekuasaan Kehakiman Yang Merdeka Varia Peradilan Majalah Hukum Jakarta Mei 2009.

[2] Hukum Hakim dan Masyarakat Varia Peradilan Majalah Hukum Jakarta Maret 2009.

[3] Yahya Harahap.M Hukum Acara Perdata tentang Gugatan Persidangan Pembuktian dan Putusan Pengadilan Ed-VII Sinar Grafika Jakarta April 2008.

[4] Burhan Ashshofa 2007 Metode Penelitian Hukum PT Rineka Cipta Jakarta.

[5] Antonius Sudirman 2007 Hati Nurani Hakim dan Putusannya Suatu pendekatan dari Perspektif IImu Hukum Perilaku (Behavioral Jurisprudence) Case on Bismar Siregar Ed-I PT Citra Aditya Bakti Bandung

[6] Adjie Habieb 2009 Meneropong Khasanah Notaris dan PPAT Indonesia PT. Citra Aditya Bakti Bandung.

[7] 2008 Sanksi Perdata dan Administrasi Terhadap Notaris sebagai Pejabat Publik Bandung:Refika Aditama.

[8] Adjie Habib 2011 Kebatalan Dan Pembatalan Akta Notaris Bandung Refika Aditama.

[9] Simbolon Tamba. Notary agreement restricted In Civil Dispute In Semarang District Court (Case Study Case Decision No. 14 / Pdt.G / 2005 / PN. Smrg): Thesis Semarang Graduate School of Notary Master Study Program 2008.

[10] Law of the Republic of Indonesia Number 30 Of 2004 on Notary.

[11] Law of the Republic of Indonesia Number 48 Of 2009 concerning Judicial Authority.

[12] The draft Civil Code (Burgerlijk Wetboek) Equipped with Law Number 18 Of 2003 concerning Advocates Bandung: Umbara 2007.

[13] Compilation of Islamic Law in the Law of the Republic of Indonesia Number 1 Of 1974 About Marriage and Islamic Law Compilation Equipped Law of the Republic of Indonesia Number 12 Of 2006 on Citizenship of the Republic of Indonesia Bandung: Umbara 2010.

[14] Government Regulation No. 37 Of 1998 on Regulations Title Agreement Land

[15] Pamekasan Religion Court Decision No. 1131 / Pdt.G / 2011 / PA. Pmk) ". 